\title{
Die antieke Griekse lofgedig
}

\author{
W.J. Henderson \\ Departement Griekse \& Latynse Studies \\ Randse Afrikaanse Universiteit \\ JOHANNESBURG
}

\begin{abstract}
Ancient Greek praise poems

Arguing from both the surviving texts themselves and from ancient theorists, the present article deals with early Greek lyric poems in praise of human beings. This type of lyric falls under the more "secular types" of ancient Greek lyric, in the sense that they were addressed, not to a divine being, but to a human being. The context or space of such "secular" lyric performance includes, not only the public gathering of officials and the populace, but also the private and intimate circle of individuals with shared interests. Both choral odes and solo-lyrics are therefore involved. The lyric types discussed are the praise poem, the war poem, the political poem and the dirge.
\end{abstract}

\section{Inleiding}

Terwyl al die geleenthede waartydens liriese poësie in antieke Griekeland voorgedra is, in oorsprong en essensie ingebed was in 'n gemeenskaplike religieuse seremonie ter ere van 'n bepaalde godheid, het vele menslike aktiwiteite 'n meer sekulêre aspek ontwikkel. Die konteks of ruimte van die liriese voordrag is uitgebrei sodat dit nie net die openbare byeenkoms van amptenare en gemeenskap ingesluit het nie, maar toenemend ook die private en intieme sirkel van individue met gemeenskaplike belange.

Die vorm en inhoud van die gedigte reflekteer hierdie verskil van ruimte en funksie: naas die koorliedere, met hulle grootse struktuur en opgevoer deur 'n koor en musiekensemble tydens 'n openbare geleentheid, vind ons die sololiedere. Hierdie sololiedere het meestal bestaan uit kort strofes, dikwels deur die digter self gesing, terwyl hy homself op die lier begelei, en het 'n meer persoonlike tema en stemming bevat. In teenstelling tot die "religieuse" lirieke, wat tot een of ander godheid gerig is, is die geadresseerde in die "sekulêre" liriek in die meeste gevalle ' $n$ mens. Die kriterium van die indeling religieussekulêr is dus nie soseer die aard van die geleentheid nie (baie waarvan in oorsprong in elk geval religieus was), maar die wese aan wie die gedig gerig is. 
Dit is ' $n$ indeling wat in Homeros reeds herkenbaar is (Henderson, 1994:146147).

Met die oorblywende tekste self en die uitsprake van die antieke teoretici as basis, behandel die huidige artikel een tipe onder die "sekulêre" antieke Griekse lirieksoorte, die loflied, en verwante tipes soos die oorlogs- en politieke lied en die klaaglied. Hierdie gedigte verskyn in twee gedaantes: dié wat vir die breër publiek bedoel was, en dié wat tot nıeer intieme kringe beperk was.

\section{Openbare geleenthede}

\subsection{Die feeste}

Oor die hele antieke Helleense wêreld heen is feeste gehou waartydens daar, op nasionale en plaaslike vlak, in atletiese en poëtiese kompetisies gewedywer is. Dat hierdie spele in voor-historiese tye ontstaan het as deel van die begrafnisseremonies van helde blyk uit die lykspele vir Achilleus in Homeros, Ilias 23; die begrafnis van Pelias by Stesichoros, frr. 1-3 Page en die verband van die Olimpiese spele met die begrafnis van Pelops by Pindaros, Olimpiese ode 1 (kyk Huizinga, 1938:103-109, 170 e.v., 227 e.v.; Pickard-Cambridge, 1968; Parke, 1977). ${ }^{1}$

Die vier groot nasionale of pan-Helleense feeste was die Olimpiese fees (ter ere van Zeus te Olimpia), die Puthiese fees (ter ere van Apollo by Delphi), die Nemeiese fees (ter ere van Zeus by Nemea), en die Isthmiese fees (ter ere van Poseidon by Korinthe). Ons kan die siklus van hierdie feeste rekonstnueer. Die Olimpiese jaartelling het naamlik in Augustus begin en oor ' $n$ periode van vier jaar gestrek. Gedurende die volgende olimpiade is die patroon herhaal.

Uit die tabel wat die siklus van die feeste aandui, blyk die volgende:

* In elke jaar van die olimpiese siklus was daar ten minste een nasionale fees, en in elke eerste en derde jaar twee feeste.

* Die Isthmia en Nemea het mekaar elke jaar afgewissel, en die Olimpia en Puthia elke twee olimpiese jare.

* Die Isthmia het in die tweede en vierde jaar van elke Olimpiade geval, die Nemea in die eerste en derde, en die Puthia in die derde jaar.

1 Die gedigte en fragmente word genommer volgens die volgende uitgawes: Campbell, 1988, 1990-1993; Diehl, 1935-42; Lobel \& Page, 1968; Page, 1962; Snell \& Maehler, 1970 en 1975 . Vir Engelse vertalings van die relevante gedigte en fragmente, kyk Campbell, 1988, 1990-1993 en Sandys, 1961. 


\begin{tabular}{llll} 
& $\begin{array}{l}\text { Augustus } \\
\text { Somer }\end{array}$ & $\begin{array}{l}\text { April } \\
\text { Lente }\end{array}$ & $\begin{array}{l}\text { Julie } \\
\text { Somer }\end{array}$ \\
\hline Jaar 1 & Olimpia & - & Nemea \\
Jaar 2 & - & Isthmia & - \\
Jaar 3 & Puthia & - & Nemea \\
Jaar 4 & - & Isthmia & -
\end{tabular}

Naas hierdie nasionale feeste was daar nog die plaaslike feeste en spele, waarvan die omvang deur Pindaros vir ons geskets word. In sy oorwinningslied vir Xenophon van Korinthe (Olimpiese ode 13) loof hy die familie se tradisie van sukses: naas die Olimpia, Isthmia, Nemea en Puthia, noem hy die spele van Argos, Thebe, Arkadië, Athene, Pellênê, Síkuon, Mégara, Eleusis, Marathon, asook die spele op die eilande Aígina, Sicilië en Euboia. Pindaros sluit dan af: " $\ldots$ dwarsdeur die hele Hellas sal jy hulle soek en vind, meer as wat ons kan sien".

Poësie het ook tydens hierdie feeste gefigureer - 'n gegewe wat onder andere blyk uit 'n opmerking van Plato (Hipparchus 228B) dat die Atheense tiran Hipparchos rapsodiste na die Panathenaia in Athene laat bring het om Homeros se twee eposse van begin tot einde in aflosbeurte voor te dra. Ook word gestel dat Hipparchos Anakreon laat kom het - alles om die kulturele lewe van die volk te verbeter. Tydens die Spartaanse Karneia het liriese poësie 'n prominente plek gehad: Terpandros van Lesbos het daar gewen, en Perikleitos was die laaste van die lirici van Lesbos om daar sukses te behaal (Athenaios 14.635D; Ps.-Plutarchos, De musica 3; Pindaros, Puthiese ode 5.72-81). Ook tydens die Gumnopaidia-fees in Sparta is liedere van Alkman gedans en gesing (Athenaios 15.678B; Ps.-Plutarchos, De musica 9).

Dit sal onmiddellik besef word hoe hierdie gebruik 'n voortgesette behoefte aan gedigte deur professionele digters geskep het - gedigte om in die afwesigheid van nuusmedia en met 'n minimum gebruik van ander rekordhouding, die geleenthede en oorwinnaars te roem. Wybeelde met inskripsies het weliswaar voorgekom, maar die inskripsies op hierdie beelde was uiteraard kort en beperk tot een geografiese plek. Ook was hierdie wybeelde en hul inskripsies kennelik meer as dankoffer aan 'n beskermende godheid as vir publisiteit bedoel. Die eintlike medium wat die prestasie van die wenners geroem en verewig het, was geleentheidspoësie. 


\subsection{Die epinikion}

Die liriekvorm wat hierdie atletiese oorwinnings moes besing, herdenk en verewig, was die epiníkion of oorwinningslied, 'n spesiale soort enkômion, die pryslied wat "aan mense" gerig is. In Aleksandrynse tye is dit só gedefmieer: "Die epinikos is 'n gedig wat 'n enkômion van oorwinnaars omsluit en wat op en deur daardie oorwinning geskep is", of: "Die epinikos is by daardie geleentheid van die oorwinning vir die voorstes (wenners) in die spele geskryf" (Dionusios Thrax; vgl. Photios, Bibliotheca 321A2-3; Crusius, 1907; Färber, 1936:35-36; Harvey, 1955:163 e.v.).

Die epinikia van Simonides, Bakchulides en veral van Pindaros ontvou 'n hele wêreld voor die leser se oë. Pindaros se epinikia is volledige gedigte, maar selfs in die fragmente van die ander digters skemer die besonderhede van hierdie wêreld van glorieryke menslike, maar goddelik-bepaalde atletiese prestasie deur. Gewoonlik kan die bepaalde spele, die wenner en die item geïdentifiseer word.

Simonides het groot aansien vir sy epiníkia geniet (vgl. Theokritos 16.34-47). Ongelukkig het slegs enkele fragmente behoue gebly. Uit die karige reste kan elemente van die voor-Pindariese epinikion nagespeur word. In Simonides se bondige epigramme (frr. 148, 149, 151 Diehl) verskyn die "resep" of formule vir hierdie soort gedig. Die genre is wel anders, maar die wy-inskripsie en die epinikion dien dieselfde doel en het dus dieselfde basiese bestanddele: die naam van die wenner, sy vader, stad, item en plek. Op hierdie besonderhede word uitgebrei en gevarieer: familieverbintenisse, roem en die mitiese verlede van die stad, die besonderhede van die wedloop en feesplek (kyk frr. 1-4, 10-11 Page; 111, 148-151 Diehl).

Die digterlike nalatenskap van Simonides se kleinneef Bakchulides is minder deur tyd en omstandigheid verwoes. Hierdie twee digters van Keos was professionele teenstanders van Pindaros, veral vir die guns en opdragte van die ryk en magtige tiranne van Sicilië (vgl. die scholias by Pindaros, Olimpiese ode 2.154; Nemeiese ode 3.143; en Puthiese ode 2.97, 131, 166). Hierdie poëtiese uitinge impliseer duidelik, te midde van die konvensies en tradisie van die epinikion, verskille van poëtiese siening en skepping wat natuurlikerwys in die gedigte gereflekteer sou wees.

Sekere gemeenskaplike, konstante elemente kom herhaaldelik voor, die basiese bestanddele van die patroon van verwagting wat deur die geleentheid, die gehoor, en die opdraggewer van die gedig geskep is, en waaraan die digter moes voldoen. Die vorm en voordrag is op groot skaal: lang strofes (meestal in triades van strofe, antistrofe en epode), 'n koor van danser-sangers, musiek- 
ensemble, verhewe taal en gedagtes, ernstige stemming, die inhoud op die breë publiek gerig. Die inhoud betrek in meerdere of mindere mate die volgende:

* Die wenner word met naam, vadersnaam en tuisdorp geïdentifiseer, sy en sy familie se vorige oorwinnings, ander prestasies en deugde word opgenoem (byvoorbeeld roem, rykdom, mag, vroomheid, edele stam, goeie regering, gasvryheid, liefde vir poësie, politieke, militêre en sosiale prestasies), en hy en sy familie word 'n ewe suksesvolle toekoms met die hulp van die gode toegewens.

* Die item waarin die wenner geseëvier het, word direk genoem of met parafrase gesuggereer, en die wenner se bepaalde vaardigheid, krag en vernuf word uitgesonder.

* Die bepaalde geleentheid of spele word op grond van spesifieke aspekte direk of indirek geïdentifiseer:

- $\quad$ Die Olimpiese spele as die grootste en roemrykste spele word aan Zeus, die seun van Kronos gewy. Ook spesifieke ruimtelike gegewens word vermeld: die spele vind plaas in Zeus se témenos aan die voet van die berg Kronos, naby Pisa en langs die Alpheios-rivier. Daar word soms vermeld dat die spele vierjaarliks gedurende Augustus plaasgevind het, dat dit vyf dae aangehou het en dat die wenners 'n krans van wilde olyf ontvang het.

- $\quad$ Die Puthiese spele weer, is aan Apollo gewy. Hierdie spele het plaasgevind by Delphi, naby die Kastalia-fontein, langs die plein van Kirrha, aan die voet van die berg Parnassos en die heuwel van Kirsa. Die prys was blommekranse.

- $\quad$ Die Nemeiese spele was ter ere van Zeus en het in die woud van Nemea, naby Phlios, plaasgevind. Hierdie spele het tweejaarliks plaasgevind en blommekranse is as prys ontvang.

- $\quad$ Die Isthmiese spele is aan Poseidon gewy en het plaasgevind op die Isthmos van Korinthe. Die prys vir die wenner by hierdie spele was 'n krans van wilde seldery.

* Die feesvierings word geskets, of dié by die bepaalde geleentheid, onmiddellik ná die gevierde prestasie, of dié in die wenner se tuisdorp, selfs lank na die bepaalde prestasie. In al hierdie elemente is duidelik heelwat ruimte vir variasie, en die tekste toon dit ook aan.

Die ruimte wat hierdie elemente (wenner, item, geleentheid, feesviering) in die oorblywende gedigte en fragmente opneem, is egter betreklik min. Die 
dominerende elemente, waar ook die grootste graad van variasie en individuele oorspronklikheid gevind word, is die mite en die persoonlike uiting, veral ten opsigte van wêreldbeskouing en die poësie self. Daar is wel gedigte sonder 'n mite en sonder persoonlike uitsprake oor die lewe en die poësie, maar hulle is in die minderheid. Enkele epinikia bevat wel beperkte mitologiese verwysings of exempla (kyk Bowra, 1964:278-316). Wat die mites betref, vind ons dié wat direk met die spele se godheid of legendariese oorsprong verband hou, of met die wenner se familie of tuisstad; ander mites illustreer ' $n$ morele les wat ó die hoedanighede van die wenner óf die digter se eie kyk op die lewe of poësie toelig.

Die epinikion illustreer duidelik hoe ontoereikend enige kunsmatige kategorisering van die lirieksoorte is. Die epinikion is gerig aan 'n mens wat in een of ander atletiese prestasie geseëvier het. Die geleentheid was egter 'n gereelde fees wat aan ' $n$ bepaalde god gewy is. Nog meer: die oorwinnaars het digters gehuur (antieke media-dekking!) om epinikia te komponeer (woorde, musiek, choreografie) in die week of twee van die fees. Hierdie epinikia is opgevoer tydens 'n groot openbare geleentheid op die laaste aand van die fees. Hiervoor is korter koorliedere geskep. Die ryker wenners, en veral die tiranne van Sicilië, het egter ook 'n langer komposisie bestel, om by 'n later geleentheid op te voer. Hierdie opvoerings het plaasgevind in die intiemer ruimte van die hof of aristokratiese banket, ná die wenner se terugkeer na sy tuiste. Die korter komposisie word dus die openbare een, die langer komposisie die privater een. Die onderskeiding "openbaar-religieuse koorlied" teenoor "privaat-sekulêre monodie" moet eintlik hier (en in ander gevalle) opgehef word.

\section{Private geleenthede}

\subsection{Die ruimtelike konteks}

Die wêreld van die aristokratiese man van die stadstaat het neerslag gevind in eiesoortige liriekvorms. Hierdie liedere het ontstaan in en vir die sosiopolitieke groepe (hetairelai, thiasoi) van vriende (hetairoi) van gemeenskaplike belange en klas. Die fokuspunt was normaalweg die banket of fees in 'n huis, stadsaal of paleis.

Onder die lirieksoorte wat voorgedra is tydens bankette (sumposia), openbare maar meer beperkte geleenthede as in die geval van die godsdienstige feeste, was die loflied (enkômion en épainos) en verwante tipes soos die oorlogslied (polemikón), politieke lied (stasiôtikón) en die treurlied (thrênos of epikêdeion). 'n Groot verskeidenheid motiewe is in hierdie digsoorte ineengevleg: gebede, politiek, lewenswyshede, en lofuitinge aan beroemde helde (Reitzenstein, 1893; 
Aly, 1927; Severyns, 1934:835 e.v.; Färber, 1936:37; Schmid \& Stählin, 1959-1964:I,348 e.v.).

\subsection{Die enkômion en épainos}

Die antieke teoretici onderskei tussen 'n humnos, 'n loflied aan 'n godheid, en 'n enkômion, 'n loflied aan 'n sterfling (Färber, 1936:35). Die enkômion is verder van die épainos onderskei op grond van omvang of lengte: die enkômion het 'n hele reeks goeie dade in 'n verhalende struktuur betrek, waar die épainos net een goeie daad in 'n kort bestek vir lof uitgesonder het. Aristoteles (Rhetorica 1367B27) onderskei die enkômion as die algemene en épainos as die besondere term.

Etimologies is die woord enkômion afgelei van kômê, eintlik "'n dorp", maar is ook vir "'n stadswyk" of "steeg" gebruik. Oorspronklik was dit skynbaar 'n lied waarin sekere persone van hoë aansien en amp wat die volk benadeel het, snags op straat uitgeskel of uitgejou is (Färber, 1936:36).

Aphthonios (4de of 5de eeu n.C.) definieer die enkômion en sluit byna al die tradisionele elemente in: die enkômion is narratief van aard en bevat ook die element van lofuiting; etimologies word enkômion afgelei van kômê en word dit betekenismatig onderskei van himne en épainos:

'n Enkômion is 'n beskrywende vertelling van besondere goeie dade. Dit word so genoem as gevolg van die feit dat die [mense van die] oudheid dit in die dorpswyke gesing het: hulle het [in daardie tyd] die stege "dorpies" genoem. En dit [d.i. die enkômion] word van die himne en épainos daarin onderskei dat die himne aan die gode en die enkômion aan sterflinge gerig is; en dat die épainos in 'n kort tyd [dit wil sê met minder "kuns", meer spontaan] geskep word, maar die enkômion met kunsvaardigheid [dit wil sê met groter tegniek in musiek- en woordkuns] voortgebring word (Progymnásmata 8).

Uit hierdie defmisie blyk dat die enkômion 'n meer verhewe digvorm as die épainos was.

'n Alternatiewe, minder waarskynlike, afleiding word deur Johannes Sardianos verskaf:

Maar sommige sê dat die digters hierdie liedere nie in die dorpswyke (kômai) gesing het nie, maar tydens die feestelike optogte (kômoi) en die simposia; en vandaar het die enkômion sy naam gekry, vanweë die feit dat die mense vanouds tydens een of ander feesviering ter ere van mense lofbetuiginge geuiter het - ook sodat iemand iets skertsends kon kwytraak (in Aphthonios, Progymnásmata 86). 
'n Ontleding van die bestaande voorbeelde van enkômia toon 'n totale afwesigheid van die element van uitskel: die fragmente is almal uit loftuitinge afkomstig. Die geleentheid van die opvoering is ook anders: die leser kry die indruk dat die milieu die simposium eerder as die smal straatjies is. Die logiese gevolgtrekking is dat hierdie liriekvorm, wat sy oorspronklike assosiasie met die stege of dorpswyke ook al was, teen die tyd van ons vroegste literêre voorbeelde reeds verplaas is na die geselliger atmosfeer van die banket of fees.

Die loflied of pryslied is 'n integrale deel van enige stamkultuur, en in die geval van die Grieke moes dit ook reeds vroeg in hulle geskiedenis gefigureer het. In Homeros (llias 9.189) word die "roemryke dade van manne" deur Achilleus besing terwyl net Patroklos as gehoor figureer. In Odusseia 8.62-92 is 'n pragtige episode waarin Odusseus tydens 'n onthaal van Alkinoös tot trane geroer word deur die sang en lierspel van Demodokos. Die lied was 'n enkômion van die roemryke dade van helde soos Odusseus en Achilleus en Agamemnon. Die toneel is die banket.

Alkaios is die vroegste lirikus wat in die oorgelewerde getuienis as skepper van lofliedere (épainoi) aangedui word. Hesuchios gee naamlik in sy definisie van épainos as "lofprysinge: beslissings, aanbevelings en verkiesings" die voorbeeld van Alkaios se lofliedere. Dit is egter onmoontlik om met enige mate van sekerheid enige van die bestaande fragmente van sy poësie as afkomstig van 'n épainos te bestempel. Die naaste is 'n fragment waarin hy sy broer Antimenidas vir ' $n$ besondere daad in 'n geveg saam met Babiloniërs loof (fr. 350 Lobel \& Page).

Die volgende digter van wie ' $n$ fragment oorgelewer is waarin lof as 'n element voorkom, is Ibukos, hofdigter van die tiran Polukrates van Samos. Weer is die aard van die gedig, fr. la Page, nie as 'n enkômion bewysbaar nie (kyk Barkhuizen e.a., 1988:94-109). Simonides van Keos, eers digter aan die hof van Hierôn, tiran van Sirakuse (Athenaios 14.656D; Aristoteles, Rhetorica 1391A8; Cicero, De natura deorum 1.22) en dan aan die sy van Hipparchos, tiran van Athene (Plato, Hipparchus 228B, C), het volgens die Suda-leksikon enkômia geskryf. Een fragment van Simonides sou as enkômion kon kwalifiseer. Hierdie fragment is aan die prins Skopas, seun van Kreon van Thessalië, gerig (fr. 37 Page). Bakchulides se fragment aan Hierôn (20c Snell \& Maehler) is ook nie definitief 'n enkômion nie: dit kan ook 'n epinikion of skólion (drinklied) wees.

Dit was Pindaros wat die epiníkion as 'n enkômion beskou het, en die woord gekoppel het aan die kômos, die optog wat die wenner ná sy oorwinning vergesel het. Dit spreek duidelik in verwysings in sy epinikia na die "enkômion-lied" of "enkômion" (Olimpiese ode 2.47; 10.76-77; 13.29; Puthiese 
ode 10.53-54). Net 'n paar reëls van Pindaros se fragmente het 'n enkomiese inslag wat dalk uit nie-epinikiese gedigte stam (frr. 118-121 Snell \& Maehler). Lof aan die aangesprokene is die sleuteltema van die digvorm. Daarmee is ons by die kern van die enkômion: 'n loflied gebore uit die behoefte om die heldedade van tydgenote met dié van die voorvaders in verband te bring om dit in die volksgeheue te hou en te verewig. Tipies van Pindaros word ook mitologiese voorbeelde betrek, en word die rol van die poēsie bevestig om die held en sy dade te verewig.

\subsection{Die polemikón en stasiôtikón}

Poësie wat geskep is in tye van oorlog of politieke onrus deel met lofpoësie die eienskap om waardes te identifiseer, te evalueer en te propageer. Lof word betuig teenoor diegene wat as groep of individue daardie waardes deel. Daarby kom egter ook die element van kritiek, van soms felle oordeel oor diegene wat nie daardie waardes deel nie.

Proklos identifiseer nie 'n politieke lied as 'n aparte lirieksoort nie, maar ander testimonia dui op die groepering van politieke, oorlogs- en patriotiese liedere ten minste in Aleksandrynse tye. So 'n versameling word aan Alkaios toegeskryf. Dionusios van Halikarnassos (5.421) sonder naamlik die morele toon van Alkaios se politiká vir bewondering uit, en Quintilianus (10.1) loof veral die etiese, bondige, verhewe en raak tipering in sy aanvalle op tirannie (ten koste van die simpotiese en liefdespoësie), terwyl Strabo (13.617) meld dat die politieke onrus en tirannieë in Mutilene in Alkaios se sogenaamde stasiôtiká as tema gefigureer het.

Dit was veral in die Doriese wêreld rondom Sparta en haar gebiede in Lakonië waar musiek (poësie) en oorlog verbind is. Plutarchos (Lycurgus 21) meld die Spartane se gebruik van marsjeerritmes en die fluit in veldslae. Hy meld ook (Luc. 28) dat toe Thebe Lakonië binnegeval het, die Helote-gevangenes geweier het om liedere van Terpandros, Alkman of Spendon te sing omdat hulle base, die Spartane, dit nie toegelaat het nie. Hierdie liedere was nie noodwendig oorlogsliedere of politieke liedere as sodanig nie, maar hulle sou wel 'n patriotiese inslag kon gehad het. Athenaios (14.630F; vgl. 618C) maak die opmerking dat spesiale oorlogsliedere (embatéria) deur die kinders geleer is. So 'n lirieksoort, die embatérion, word deur die Aleksandrynse teoretici gedefmieer (Polubios 4.20.12), maar ons besit alleen die oorlogsverse van Archilochos en Turtaios, jambiese digters eerder as lirici.

'n Bepaalde vaste geleentheid was daar kennelik nie, maar hierdie lirieksoort vertoon 'n gebondenheid aan 'n bepaalde gebeure, gewoonlik polities-histories eerder as mities van aard. Dit is die (dikwels harde) werklikheid van die polities-militêre wêreld wat in hierdie gedigte weerspieël word. Die gewone 
ruimte waarin 'n digter voorgedra was, was die banketsaal (byvoorbeeld fr. 38 Lobel \& Page). Dat hierdie digsoort egter nie tot die banketsaal beperk was nie, word ook bewys deur 'n opmerking van Athenaios (14.627A) dat musiek in antieke tye op die slagveld gebruik is om dapperheid aan te wakker, en dat Alkaios se poësie hiervoor gebruik is. Hy haal dan reëls aan (fr. 357 Lobel \& Page) as voorbeeld van Alkaios se oorbeklemtoning van oorlog en dapperheid ten koste van die poësie. Maar waar is die gedig oorspronklik voorgedra, op die slagveld, of tydens 'n banket? (kyk Page, 1965:209-223).

Alkaios se oorblywende fragmente bied ons die meeste voorbeelde van die patriotiese, militêre of politieke gedig. In sy bestaande fragmente is daar drie hooftemas: politieke onrus, bepeinsing oor oorlog en ballingskap.

Die algemene politieke onrus in Mutilene is deur Alkaios in die beeld van die skip van die staat verewig. Sy transformasie van die see as algemene beeld van onrustigheid en gevaar tot 'n skip op 'n onstuimige see as allegorie vir die stadstaat of faksie daarbinne staan aan die begin van 'n hele tradisie van sulke beelde (Page, 1965:179-197; Kirkwood, 1974:75-77; Bowra, 1961:152-153). Alkaios gebruik die beeld etlike male, en drie lang fragmente bevat die skip as sentrale simbool (frr. 6, 73, 326 Lobel \& Page).

Min bly oor van Alkaios se gedagtes oor die aard en implikasies van oorlog. Enkele reëls is deur latere skrywers aangehaal vir die universele geldigheid daarvan. Dit is egter onmoontlik om vas te stel uit watter soort gedig sulke reëls afkomstig is. Oorlog kan spesifiek genoem word (fr. 112.10, 330, 372, 382, 400 Lobel \& Page), maar die identifisering as dele van embatéria of polemiká bly net 'n moontlikheid.

Alkaios se ervarings en houdings kry meer fokus in 'n groep gedigte wat oor bepaalde figure handel (veral die drie tiranne, Melanchros, Mursilos en Pittakos), asook oor sy eie ballingskap. Oor eersgenoemde bestaan nog net 'n onverstaanbare reël (fr. 331 Lobel \& Page), en Murtos se dood word met vreugde begroet (fr. 332 Lobel \& Page). Dit is egter Pittakos wat in Alkaios se politieke liedere die bête noir was. 'n Hele reeks fragmente verwoord Alkaios se verbittering teenoor en minagting van hierdie gevierde leier, wat hy as die oorsaak van sy lyding in ballingskap beskou het (frr. 67, 69, 70, 72, 75, 106, 129, 130, 306 fr.9, 348, 429 Lobel \& Page).

\subsection{Die thrênos en epikêdeion}

Waar die enkômion die dade van 'n lewende man besing het, het die thrênos 'n gestorwene of gestorwenes vereer. Die Aleksandrynse bronne verskil onderling in hulle onderskeid tussen twee vorms van die klaaglied of begrafnislied, 
naamlik die epikêdeion (of epikêdion) en die thrênos (vgl. Färber, 1936:38-39; Maas, 1936; Reiner, 1938).

Die twee, epikêdion en thrênos, word in die definisies heeltemal omgeruil. Die langste testimonium, deur Ammonios (kyk Färber, 1936:II.h), bevat verskeie opvattings. Hy verwys na Truphôn wat die epikêdion met die begrafnis self in verband bring, en die thrênos met enige latere herdenking daarvan. Daarnaas teken hy die teorie van Aristokles van Rhodos op, naamlik dat die thrênos 'n lied oor 'n noodlottige of rampspoedige gebeure is. Ook bevat die thrênos 'n eie spesifieke naam en 'n weeklaag en enkômion oor die gestorwene of gestorwenes.

Ander weer beskou alle begrafnisliedere as thrênoi. Nog ander onderskei epikêdion en thrênos deur eersgenoemde as 'n épainos (loflied) aan die gestorwene te beskou en deur laasgenoemde aan die begrafnis self én die jaarlikse herdenking daarvan te koppel. Photios (Bibliotheca 321A30-31) ondersteun Truphôn se onderskeid met die byvoeging dat die epikêdion gesing word terwyl die lyk nog in staatsie lê, vóór die begrafnis.

Die begrafnislied is deur 'n koor van diensmeisies "en diegene met hulle" gesing (Ammonios). Die woord thrênos word in die testimonia afgelei van thraúein, "breek" (van die gemoed of hart), of thérein, "brand" (van smart; of brand in die verassingsproses).

Die klaaglied was uiteraard een van die vorms van die lied wat sy oorsprong in die stamkultuur gehad het, en wat dus baie vroeg in die Griekse kultuurlewe gefigureer het. 'n Begrafnistoneel met die lier in die begrafnisstoet verskyn op 'n sarkofaag van Hágia Tríada (Kreta) wat uit ongeveer 1500 v.C. dateer (afbeelding in Demargne, 1964:142). Op Griekse kruike van die Geometriese tydperk (10de-7de eeue v.C.) was die begrafnistoneel met roubeklaers in houdings van weeklaag 'n herhaalde motief (afbeeldings in Boardman e.a., 1967:plate 64, 65, 66).

Homeros verskaf die vroegste oorblywende literêre beskrywings van klaagliedtonele uit die Griekse verlede. By die dood van Achilleus se boesemvriend Patroklos is daar die gebruiklike uiterlike gebare en tekens van rou by die eerste aanhoor van die nuus van sy dood. Achilleus gooi stof en as op sy kop en trek sy hare uit. Die diensmeisies slaan op hul bors en word flou. Dan volg die algemene weeklaag van die Nereïede-nimfe saam met Achilleus se moeder, die nimf Thetis (llias 18.20-64). Later, voor die lyk gewas en gesalf, met linne bedek en op die baar geplaas is, styg die geweeklaag en gekreun van die Achajers, en veral van Achilleus, die hele nag rondom die lyk op (314-355). Die laaste fase van die begrafnisseremonie is die verbranding van die lyk op die 
brandstapel, die afsny van die hare deur die roubeklaers, die begrafnismaal en die begrafnisspele (Ilias 23.1-23).

Die begrafnis van die ander groot held, Hektor, sluit die llias af. By hierdie geleentheid sing 'n koor van vroue, asook Andromachê, Hekabê en Helena die treurliedere (24.718 e.v.). In die onderskeie weeklag van Thetis, Achilleus, Andromachê, Hekabê en Helena word die persoonlike smart van die familielid of vriend tot uiting gebring en gemeng met lof aan die gestorwene, herinnering aan gebeure in sy lewe, en die besef van die menslike lot in die aangesig van goddelike beskikking. Thetis word verder in haar optrede gedryf deur die begeerte om vertroosting aan haar bedroefde seun te bring.

Die vroegste liriese digter aan wie thrênoi toegeskryf word, is Olumpos. Volgens 'n scholias by Aristophanes (Equites 7) sou hy "klaaglied-nomol" vir fluitbegeleiding geskep het. Plutarchos deel ons mee (De musica 3) dat die fluitdigters onder andere epikêdeia gekomponeer het. Sappho gebruik die woord thrênos (fr. 33 Lobel \& Page) maar in 'n algemene eerder as 'n tegniese sin. Stesichoros se gedig oor die begrafnis van Pelias (frr. 1-3 Page) herdenk 'n mitologiese held en nie 'n werklike gestorwene nie. In elk geval is die oorblywende reëls nie genoeg om die digsoort of eienskappe daarvan aan te dui nie.

Die eerste lirikus van wie ons 'n fragment uit 'n thrênos besit, is Simonides. Die antieke testimonia beaam hierdie digvorm in sy oeuvre (die Suda-leksikon; Harpokration, Lexikon 174.15 = fr. 25P; die scholias by Theokritos 16.36 en $44=$ frr. 23 en 24 Page). Simonides het selfs in 'n kompetisie om 'n elegie vir die gesneuweldes by Marathon te komponeer die tragedieskrywer Aischulos geklop (Vita Aeschyli, Biographi Graeci 119).

Onder Simonides se oorblywende fragmente is net enkeles wat met enige mate van sekerheid as afkomstig uit thrênoi beskou kan word. Stobaios haal twee aan met die opgaaf van Simonides se versameling thrênoi as bron (Florilegium 105.9; 98.15). Die dominante tema is die menslike lot - alhoewel dít juis die rede was vir die aanhaling en dus bewaring van die reëls, en dit nie noodwendig die hooftema van die hele thrênos aandui nie (frr. 16, 18 Page). 'n Derde en vierde kon dalk ook deel van 'n thrênos gewees het; daar is geen konteks of genre-aanduidings nie, behalwe dat Stobaios dit aanhaal as 'n stelling oor die onvermydelikheid van die dood $(118.5 ; 118.6 ;$ frr. 17, 19 Page). Die aanhaling van 'n ander fragment deur Plutarchos in sy Consolatio Apollonii 11 (Moralia 107B = fr. 15 Page) sou te danke kon wees aan die feit dat die gedig eienskappe van 'n thrênos getoon het. Vir die res is daar egter net die fatalistiese toon en inhoud van die fragmente wat hulle 'n thrênos-karakter gee (frr. 20, 21, 22 Page). 
Daar is egter een beroemde fragment van nege reëls (fr. 26 Page) oor die gesneuweldes by Thermopulai wat soos 'n thrênos volgens die Aleksandrynse defmisies lyk, alhoewel Diodorus Siculus (11.11.6), wat die fragment aanhaal, die gedig waaruit die reëls kom, beskryf as 'n "enkômion paslik vir die gestorwenes se glorieryke daad". Ook moderne kritici verskil steeds onderling oor die aard van die reëls (Bowra, 1961:345-349; Campbell, 1982:383; Gerber, 1970:314-317; Smyth, 1963:lxxix; Harvey, 1955:163-166).

Die eienskappe wat die Aleksandrynse geleerdes (en ook ons) in 'n klaaglied sou verwag, is wel teenwoordig: die vermelding van die gestorwene of gestorwenes, ' $n$ bepaalde gebeure wat die treurige geleentheid veroorsaak het, en 'n graf. Ook word elemente van die openbare seremonie genoem, byvoorbeeld kruike met wyn om die beendere na verassing te was. Drie gedagtes domineer die reëls: die besef van menslike sterflikheid en beperktheid, die consolatio aan die aanwesiges en naasbestaandes in terme van die versekering van ewige glorie en roem, en die bevestiging van menslike durf en moed in die aangesig van die onvermydelike dood. Dat sulke lof aan die gestorwenes, en aan 'n individu soos Leonidas, op die grens van 'n enkômion beweeg, is onvermydelik. 'n Streng afbakening tussen aangrensende liriese digsoorte vervaag in 'n geleentheidsgedig wat sowel loof as treur (kyk verder Barkhuizen e.a., 1988:145-151).

Onder Pindaros se fragmente het gedeeltes uit treurliedere behoue gebly. In sommige fragmente (frr. 128a, b, e, f Snell \& Maehler) kan net enkele woorde uitgeken word. Ander fragmente toon die consolatio-element wat natuurlik die rede vir die aanhaling deur 'n latere skrywer van die betrokke reël of reëls was (frr. 131b, 134-137 Snell \& Maehler). Vyf fragmente is lank genoeg om 'n idee te gee van Pindaros se thrênoi (frr. 128c, 129, 130, 131a, 133 Snell \& Maehler). Hierdie fragmente vertoon die gebruiklike verwysing na die gestorwene, asook die consolatio aan die agtergeblewenes. In die treurliedere van Simonides skemer 'n fatalisme deur. Vir hom word die beperktheid en fmaliteit van die menslike bestaan alleen deur die heugenis van die agtergeblewenes en nageslagte verlig. By sy jonger tydgenoot Pindaros kry die thrênos 'n religieuse dimensie. Die vertroosting lê vir hom in die idee van die onsterflikheid van die siel in ewige saligheid. Nog meer: soos elders in die poësie van Pindaros, is daar die bevestiging van en nadenke oor die mag van die poësie om sowel die gestorwene se nagedagtenis te verewig as om die agtergeblewenes se smart te heel.

\section{Slot}

Lofpoësie ter ere van mense wat gepresteer het, het in die antieke Griekse wêreld 'n belangrike rol gespeel. Lofpoësie was ingebed in die sosiale, 
politieke, militêre en godsdienstige lewe, en het tydens private sowel as openbare geleenthede tot uiting gekom. Hierdie lofpoësie het dan ook neerslag gevind in verskeie vorms, by verskillende geleenthede en wyses van voordrag: die oorwinningslied vir 'n atleet, die lofprysing van 'n regeerder, politikus of generaal, die treurlied vir gevalle helde. Uiteraard reflekteer die lofpoësie hoofsaaklik die opvattings, denke, optredes en waardes van die aristokratiese laag van die bevolking - dit was immers aristokrate wat vanuit hulle posisie in die samelewing die prestasies behaal het en wat die digters kon betaal vir hulle verse. 'n Saak van louter vleiery of propaganda was dit egter nie: telkens is daar in die oorblywende tekste tekens van kritiek op persone, groepe en verskynsels. Die digters was deurgaans besig om die prestasie, waardes en ideale van die gemeenskap te formuleer, te ontleed en oor te dra. Selfs in die skrale oorblyfsels van die tekste kan ons hierdie waardestelsel en sy verwesenliking (of nie-verwesenliking) terugvind. Sodoende kan ons hierdie beskawing en hierdie mense in die stadstate van Griekeland, vir die vier eeue vanaf ongeveer 700 tot 300 v.C., beter begryp.

\section{Bibliografie}

Aly, W. 1927. Skolion. In: Paully, A.F., Wissowa, G. \& Kroll, W. (reds.) Realencyclopädie der classischen Altertumswissenschaft. Stuttgart : Alfred Druckenmüller Verlag. IIIA.1, kol. 562.

Barkhuizen, J.H., Henderson, W.J. \& Van Rooy, C.A. 1988. Kalliope. Band

II: 'n Bloemlesing van Griekse liriese poësie van Alkman tot Pindaros.

Pretoria : Universiteit van Suid-Afrika.

Boardman, J. et al. 1967. The art and architecture of ancient Greece. London: Thames \& Hudson.

Bowra, C.M. 1961. Greek lyric poetry. 2e uitgawe. Oxford: University Press [1936].

Bowra, C.M. 1964. Pindar. Oxford : Clarendon Press.

Campbell, D.A. 1982. Greek lyric poetry. A selection of early Greek lyric, elegiac \& iambic poetry. Bristol : Bristol Classical Press. [Macmillan 1967.]

Campbell, D.A. 1988. Greek lyric. Vol. II: Anacreon, Anacreontea, choral lyric from Olympus to Alcman. Cambridge, Mass. : Harvard University Press.

Campbell, D.A. 1990. Greek lyric. Vol. I: Sappho and Alcaeus. Cambridge, Mass. : Harvard University Press.

Campbell, D.A. 1991. Greek lyric. Vol. III: Stesichorus, Ibycus, Simonides, and others. Cambridge, Mass. : Harvard University Press.

Campbell, D.A. 1992. Greek lyric. Vol. IV: Bacchylides, Corinna, and others. Cambridge, Mass. : Harvard University Press. 
Campbell, D.A. 1993. Greek lyric. Vol. V: The new school of poetry. Cambridge, Mass. : Harvard University Press.

Crusius, O. 1907. Epinikion. In: Paully, A.F., Wissowa, G. \& Kroll, W. (reds.) Realencyclopädie der classischen Altertumswissenschaft. Stuttgart : Alfred Druckenmüller Verlag. VI.1, kol. 183-184.

Demargne, P. 1964. Aegean art. The origins of Greek art. (Vertaal deur S. Gilbert \& J. Emmons.) London: Thames \& Hudson.

Diehl, E. 1935-42. Anthologia Lyrica Graeca. Leipzig : Teubner Verlaggesellschaft.

Färber, H. 1936. Die Lyrik in der Kunsttheorie der Antike. München : Neuer Filser-Verlag.

Gerber, D.E. 1970. Euterpe. An anthology of early Greek lyric, elegiac, and iambic poetry. Amsterdam : Hakkert.

Harvey, A.E. 1955. The classification of Greek lyric poetry. Classical Quarterly, 49:157-175.

Henderson, W.J. 1994. Die klassifikasie van die antieke Griekse liriekvorms. Literator, 15(1):145-157.

Huizinga, J. 1938. Homo ludens. Proeve eener bepaling van het spel-element der cultuur. Haarlem : Tjeenk Willink.

Kirkwood, G.M. 1974. Early Greek monody. The history of a poetic type. Ithaca-London : Comell University Press.

Lobel, E. \& Page, D.L. 1968. Poetarum Lesbiorum Fragmenta. Oxford : Clarendon Press [1955].

Maas, P. 1936. Threnos. In: Paully, A.F., Wissowa, G. \& Kroll, W. (reds.) Alfred Druckenmüller Verlag. VIA.1, kol. 596-597.

Page, D.L. 1962. Poetae melici Graeci. Oxford : Clarendon Press.

Page, D.L. 1965. Sappho and Alcaeus. Oxford : Clarendon Press.

Parke, H.W. 1977. Festivals of the Athenians. New York : Cornell University Press.

Pickard-Cambridge, A.W. 1968. The dramatic festivals of Athens. (2e hersiene uitgawe deur J. Gould \& D.M. Lewis.) Oxford : Clarendon Press.

Reiner, E. 1938. Die rituelle Totenklage der Griechen. Stuttgart : Kohlhammer.

Reitzenstein, R. 1893. Epigramm und Skolion. Ein Beitrag zur Geschichte der alexandrinischen Dichtung. Giessen : J. Richter. (Herdruk 1970. Hildesheim : Georg Olms.)

Sandys, J.E. 1961. The odes of Pindar, including the principal fragments. London : William Heinemann.

Schmid, W. \& Stählin, O. 1959-1964. Geschichte der griechischen Literatur. München : C.H. Beck. 
Severyns, A. 1934. Proclos et la chanson de table. Mélanges Bidez. Brussel : Université libre de Bruxelles. p. 835-856.

Smyth, H.W. 1963. Greek melic poets. New York : Biblo \& Tannen.

Snell, B. \& Maehler, H. 1970. Bacchylidis carmina cum fragmentis. Leipzig : Teubner Verlaggesellschaft.

Snell, B. \& Maehler, H. 1975. Pindari carmina cum fragmentis, Pars II. Fragmenta. Leipzig : Teubner Verlaggesellschaft. 